\title{
Contextualizing Social Media Ecology and Its Pedagogical Affordances: The Perspective of High School Teachers
}

\author{
Wilson O. Otchie, Margus Pedaste, Emanuele Bardone and Irene-Angelica Chounta \\ Institute of Education, University of Tartu, Estonia \\ otchie@ut.ee \\ margus.pedaste@ut.ee \\ emanuele.bardone@ut.ee \\ angeliki.eirini.chounta@ut.ee
}

\begin{abstract}
The potential of social media technology has made its use a daily habit among individuals, institutions, and communities. However, several studies on technology adoption, especially social media use in education, focus more on its impact on the student than the teacher, who is generally perceived as a key stakeholder. This study used purposive sampling to select teachers who taught grades 7-10 and had used social media in their teaching activities. In-depth interviews were carried out with participating teachers to get their opinions and perspectives about how they used social media in their teaching activities $(\mathrm{N}=11)$. Inductive and deductive coding were used for the latent content analysis and four categories emerged: (1) SM technology in the classroom, (2) positive perceived contextual affordances, (3) negative perceived contextual affordances, and (4) support for social media. Results of the study show that, besides the schools' learning management systems, YouTube was the major SM app that was regularly used by participants in their lessons. Also, all participating teachers expressed their interest in teaching with social media. However, they cited some challenges as weaknesses towards social media use in teaching.
\end{abstract}

Keywords: social media; ecology; affordances; contextual use; operational use; formal learning; informal learning

\section{Background}

In recent years, social media, social media technology or social media tools (hereafter SM), has seen an enormous growth in terms of the number of users. In 2019, Facebook had 2.3 billion monthly users whilst Twitter had more than 321 million active users (Statista.com, 2019). Historically, Kaplan and Haenlein (2010) defined SM as "a group of Internet-based applications that build on the ideological and technological foundations of Web 2.0, which allows the creation and exchange of user-generated content". However, the continued evolution of SM comes with different user definitions, concepts, and implications (Greenhow and Chapman, 2020; Fox and McEwan, 2017). In the context of this study, we define SM as Web 2.0 internet-based applications that feature user-generated content, profiles for the site or app created by users, and the development of online social networks by connecting a user's profile with those of other individuals or groups within the system Greenhow and Chapman, 2020; Obar and Wildman, 2015). Facebook, WhatsApp, Twitter, Instagram, LinkedIn, Skype, Google Classroom and YouTube are a few examples of popular SM applications (Calvert, 2015). Given the definition of SM, many other tools also fall into this category. Some other technology tools, however, are not so straightforwardly categorized as SM: e.g., activities such as editing a Word file, performing a web search, filling in an assessment, watching a video on one's computer, etc.

Our paper refers to SM as an ecology. The term SM ecology emerged from Postman's (1970) definition of media ecology as "the study of media as environments" (Scolari, 2012, p. 205). Essentially, SM applications are never used in isolation; hence, it is worth referring to them as an ecology rather than a collection of separate applications. Thus, this environment comprises all SM networks or applications (Zhao, Lampe and Ellison 2016). For instance, Facebook, which is an application in the ecology, occupies a specific niche but interrelates with other applications within the ecology. Consequently, these applications and services have implications that could be political, social, educational, or economic.

SM has the potential to be used in different contexts, and this attracts growing interest in diverse disciplines. Many corporate organizations, communities, individuals as well as some students and their teachers are already using it in their own contexts (Raut and Patil, 2016).

Essentially, SM has become a ubiquitous toolkit that is used daily among individuals, and largely with the young adult population (Al Alwan et al., 2017; Dwivedi et al., 2016; Kapoor and Dwivedi, 2015); but most importantly, 
it has an impact on where or how people learn (Greenhow, Robelia, and Hughes, 2009). Thus, SM facilitates social, active, and interactive learning, which supports the social constructivist theory of learning (Vygotsky, 1978).

For example, in many universities and colleges, SM is used for institutional programmes and activities (Sudha and Kavitha, 2016) as well as for social interaction (Alt, 2017). The drive and enthusiasm by educators and researchers towards accepting SM as a potential pedagogical resource has not come as a surprise. According to Silius, Kailanto, and Tervakari (2011), SM facilitates learning and makes it possible for students to actively participate in online communities by creating, communicating, sharing educational resources, and sharing opinions (Cronje, 2020; Karkar, Fatlawi and Al-Jobouri, 2020; Kibuku, Ochieng, and Wausi, 2020). It also empowers students to connect, thus facilitating the establishment of online discussion groups. Another advantage that could potentially be pedagogical is the ability to reach global audiences much faster. Also, one needs only a digital device (desktop, laptop, or smartphone) and internet service to access SM. Furthermore, SM is user-friendly and self-scaffolding; thus, one does not need to be highly skilled to use it. Additionally, it is very interactive and can be easily accessed anywhere and anytime, which removes the barriers of space and time (Cronje, 2020). These perspectives were also amplified in a study where Manca and Ranieri (2013) discovered that teachers use SM to engage students through online group discussion, interaction, and information dissemination. Also, in a related study, Ramstad and Swenson (2017) investigated how SM impacts students' classroom participation. Thus, many stakeholders in education and the research community have seen SM as a valuable option because of its potential pedagogical affordances (Sudha and Kavitha, 2016). In essence, SM has created a learning environment where there is a diversity of learning options, such as lifelong learning, formal learning, informal learning, etc. (Greenhow and Lewin, 2015; Peters and Romero, 2019)

It is very important to mention that originally most SM applications were not designed for pedagogical use; nonetheless, teachers are appropriating them in the context of teaching and learning. Although SM technology use in the classroom is potentially student-centred and constructivist-driven, teachers are yet to discover the best way technology tools can help them effectively achieve their pedagogical objectives (Kopcha et al., 2020). Incidentally, this has ignited interest in the study into SM use in education (Van Osch and Coursaris, 2015).

Literature shows a number of reviews on the generic use of SM in education (Fox and Bird, 2017; RodríguezHoyos, Haya Salmón, and Fernández-Díaz, 2015), educational affordances of Facebook (Barrot, 2018; Chugh, 2018; Manca and Ranieri, 2016; Manca and Whitworth, 2018; Nui, 2017; Voivonta and Avraamidou, 2018), Twitter as a potential pedagogical tool (Gao, Luo, and Zhang, 2012; Tang and Hew, 2017), global outlook on SM literacy development (Manca, Bocconi, and Gleason, 2021), and professional development using SM (Bruguera, Guitert, and Romeu, 2019; Lantz-Andersson, Lundin and Selwyn, 2018; Macià and Garcia, 2016).

Other studies have tried to establish a connection between formal and informal use of SM in the context of learning ecologies (Greenhow and Lewin, 2015; Peters and Romero, 2019). According to Greenhow and Lewin, SM has the potential to bridge the gap between formal and informal digital literacies. This was supported by Peters and Romero, who argued that learning opportunities are accessible across learning ecologies (formal and informal) through digital resources. Essentially, digital literacies (e.g., skills and competencies) that teachers and students bring into the classroom are a result of informal learning. For instance, the skills of using smart digital devices and most applications including SM are most often acquired outside the classroom. However, these skills directly contribute to using SM technology in the context of formal learning. In this regard, informal learning, which is more experiential, practical and skill-driven, could potentially bridge the gap in articulating the contextual use of SM in education.

Indeed, a few studies have focused on secondary education use of SM in the context of K-12 education: for example, studies showing pedagogical use of SM in general and specifically Facebook in K-12 formal learning and their effectiveness at improving students' learning (Alias et al., 2013; Greenhow and Askari, 2017; Veira, Leacock, and Warrican, 2014) and SM features having more affordances for teachers to achieve their objectives in classroom teaching and their professional development within the formal and informal learning context (Greenhow et al., 2020). Also, a review has been done by Greenhow and Askari (2020) on high(secondary) school students' integration of the distinct and complex literacies they acquire from SM into the formal learning context. 
However, regardless of the relatively small number of studies on SM educational use in high schools (or secondary schools) for learning, the general outlook of research on the educational use of SM concentrates more on university education and professional development. Similarly, these studies do not give us a straightforward answer as to the way to go, especially in teaching with SM in high schools (see Otchie and Pedaste, 2020).

In the literature, we also find a polarization between studies looking at SM as a potential pedagogical tool and those that see SM as a mere distraction (Otchie and Pedaste, 2020). In order to try to bridge the gap, the first step to make is to disambiguate the amorphous term use of SM. In other words, we claim that failing to disambiguate the term use of SM may lead to the aforementioned gap and consequently the impossibility to reach a better understanding as to how SM can be used for and in education.

To this end, the first step we make is to review the literature on the affordances of SM and then to present a theoretical framework based on the distinction between operational use and contextual use of SM, within which the concept of affordance is used to specify how teachers' meaningful use of SM comes about. Subsequently, we put this framework and related theories to use by looking at the way in which high(secondary) school teachers articulate the contextual use of SM in their own teaching practice.

Therefore, what we are focusing on is the experiences and perspectives of teachers' contextual use of SM in teaching across some selected high schools in Estonia.

Framing the narrative around teachers in Estonia is not a coincidence; rather, this was due to the perceived high degree of technology tools use and its appreciation in Estonia (OECD, 2014). Furthermore, since teaching and learning technically involve a teacher and a student, it is very important to closely look at how their roles in using SM contextually or otherwise affect the teaching and learning process. Therefore, the purpose of this study was to explore the way teachers articulate the use of SM in their own practice.

\section{Literature review}

Gibson's (1979) ecological meaning of affordances is reflected in our ability to use tools effectively. According to Gibson, affordances refer to the environment's "action possibilities" for the user. On the other hand, Norman (1988) considers affordances in terms of perception. Thus physical and perceived affordances respectively. According to him, physical affordances are what an object can genuinely do in terms of its physical properties. However, perceived affordances are the things we believe the object can be utilized for. As a result, Polanyi (1962) takes a distinct approach to this. Effective tool use, he believes, is a set of hidden abilities which he termed tacit knowledge. Relationship is the unifying thread that runs across all of their beliefs, regardless of their varied perspectives. Our ability to efficiently use any tool is largely dictated by our relationship with it. As a result, our repeated interactions with tools provide us with more experience, which may contribute to the formation of our perceptions about the tool.

So, the concept of affordance in terms of our relationship with tools is seen as very critical and equally important for developing teachers' understanding about meaningful technology use in teaching and learning (Angeli and Valanides, 2009; Krauskopf, Zahn and Hesse, 2015). The ease of use and interactive affordances of technology tools help teachers with some technical knowledge and skills to operate these tools to identify and familiarize themselves with its functionalities which Bernhard, Recker and Burton-Jones (2013) termed technical affordances or, to use our own terminology, operational affordances. However, previous studies have failed to give a clear account of how this could lead to learning (Oliver, 2013). Indeed, this unambiguously supports the fact that we do not really understand how teachers perceive and actualize these affordances in a tool (Angeli and Valanides, 2018). However, we do know that teachers can begin to meaningfully teach lessons with SM, and this is possible when teachers can integrate tacit knowledge to technological knowledge (operational skills), content knowledge, and pedagogical knowledge (Mishra and Koehler, 2006). Therefore, a better understanding of the concept of affordance and its relationship with teachers' knowledge development could help in training teachers to meaningfully and effectively use SM in their lessons (Haines, 2015). The differences between the operational and contextual levels are summarized in Table 1.

Meanwhile, other scholars perceive affordance in SM from the social constructivist perspective: As an active social learning platform that allows learners to construct knowledge and to make learning more interactive and student-centred (Manca and Ranieri, 2013; Siemens and Weller, 2011). As learning becomes more social, 
pragmatic and interactive, social constructivism tries to advance social interactions between students where the focus is on construction and sharing of knowledge (Vygotsky, 1978). Digital technology, therefore, gives access and leverage to free online learning resources, which have largely boosted students' interest and capacities to construct and share knowledge regardless of social or geographical isolation (Greenhow and Chapman, 2020). This was highlighted by Jonassen, Carr, and Yueh (1998) in the statement "Technologies should not support learning by attempting to instruct the learners, but rather should be used as knowledge construction tools that students learn with, not from." (p. 24)

The value of SM also lies in its affordances as a tool that updates the entire community including students and their parents about activities in the classroom (Manca, Bocconi and Gleason, 2021). The pedagogical potential of SM lies in the fact that it supports collaborative and active learning, is relational and contributes to social and civic participation among others (Galvin and Greenhow, 2020; Greenhow and Chapman, 2020; Manca, Bocconi and Gleason., 2021). Here, Gibson, Norman and Polanyi hold the same views on the importance of relationships when it comes to active learning or constructing knowledge.

In looking at this study through the ecological learning concepts, we then situate SM as a tool that has the affordance for diverse options of learning. A learning ecology comprises a set of contexts and interaction processes used in physical or virtual spaces that provides learning opportunities (Barron, 2004). It also gives students diverse experiences outside real life (Mar and Oatley, 2008; Merkt, 2014). Learning ecology is a new approach to learning which uses technology to scaffold learning. For example, informal learning, formal learning, lifelong learning and professional development are all options that could potentially be conducted through virtual spaces using digital tools.

This learning approach has a very important and interesting link to this study. On the one hand, it allows learners to freely access active and interactive learning through informal means. Thus, connecting the concepts of relationships to the construction of knowledge in understanding one's environment. In this whole process the learner (user) is directly and actively immersed in the knowledge construction process. On the other hand, it promotes skills development, experiential learning, critical thinking, and other tacit knowledge dimensions. Thus, it becomes imperative for teachers to build relationships with technologies to understand using them in the context of teaching and learning (Oliver, 2016; Stevenson et al., 2019). This could potentially bridge the gap between formal learning and other dimensions of learning. So, we find all these concepts more or less interrelated and directly playing out in the context of articulating SM technology in any form of learning.

Ultimately, the challenges of inadequate technological support and access in schools cannot be underestimated (Rasheed, Kamsin and Abdullah, 2020; Taghizadeh, and Hasani Yourdshahi, 2020). According to Kerckaert, Vanderlinde, and van Braak (2015), teachers' interactions with technology, their understanding of technology, and their pedagogical knowledge can all affect how they use technology in their classrooms. Essentially, teachers must be trained to consider the relationship between operational use and using technology in different contexts as part of their professional development programs in technology. As a result, it is very important that stakeholders provide all educational institutions with technology resources and adequate funding (Dillenbourg, 2008; Taghizadeh, and Hasani Yourdshahi, 2020). Aside from all of SM's potentials, stakeholders' views on it as a pedagogical resource are mixed. Thus, regardless of its pedagogical potentials, some stakeholders still regard SM as a learning distraction (Otchie and Pedaste, 2020).

Table 1: Differences between operational and contextual levels

\begin{tabular}{ll}
\hline Operational level & Contextual level \\
\hline Functionalities are operated & Affordances are perceived in the context \\
Technology as designed & Technology as in use \\
The use is identified prior to use & The use is defined by the users \\
Technology is separate from us & Technology is put to use and thus becomes part of one's cognition \\
Operational functions predefined & Polysemy of use (the use is open) \\
\hline
\end{tabular}


Proficiency use can be defined and thus assessed objectively
Building relationship with the tool is key to exploring pedagogical affordances

\section{Theoretical Framework}

Several scholars have approached SM use in education from diverse theoretical models (Manca, Bocconi, and Gleason, 2021; Peters and Romero, 2019; Stevenson et al., 2019; Stewart, 2015). However, this study uses Gibson's ecological model, Polanyi's indwelling concepts, and constructivist and learning ecological concepts as a lens to have a worldview of SM use in education.

Theoretically, affordance is key to understanding the distinction between the operational and contextual use of tools, and it holds a fundamental place in this paper. The term was coined by Gibson (1986) to refer to what the environment provides the agent inhabiting it in terms of "action possibilities". Gibson's ecological concept of affordances therefore gives us an idea about how relationships facilitate our understanding of our environment. According to him, our ability to discover these affordances depends on our relationship with the environment.

Norman (1988), the first to incorporate affordances into design research and human-computer interfaces ( $\mathrm{HCl})$, takes a different approach. According to Norman, the term affordance refers to an object's perceived and actual features, particularly those that define how the object is utilized. A chair, for example, provides ("is for") support and hence allows for sitting. A chair can be carried as well (Davis \& Chouinard, 2016, p. 243; Norman, 1988, p. 9). Real affordances, according to Norman, are the functions of an object, or the potentials that the object provides. For example, a chair is used for sitting. Perceived affordances, on the other hand, are those aspects of the item that the user is aware of. For example, a chair could be used not only for sitting but also like a ladder for climbing to pick something on very high shelves. Regardless of the many points of view, the concept of affordances is applicable across disciplines, is widespread in many research, and is based on relationships.

So, in order to understand how to support and promote the use of SM in teaching and learning along with its drawbacks, we posit that it is of fundamental importance to introduce a distinction, which helps us disambiguate the term technology use in education. This can be achieved when we theorize the use of technology in teaching and learning (Oliver, 2013), that is, when we conceptually articulate the way in which we establish a relationship with our tools.

Generally speaking, when we describe technology use in teaching and learning, we tend to conflate two meanings that the term use may come to acquire, which might be an obstacle to fully understand the potentials that SM has for teaching.

In this paper, we introduce the distinction between operational use and contextual use, which we derive from Michael Polanyi's seminal work. In his The Tacit Knowledge Polanyi argued that at the phenomenological level we can identify two distinct ways in which we can interact with a tool. Firstly, we propose the term operational use - this is the situation in which the tool confronts us as an object, entirely separate from us since it has not yet been put to use. The example that Polanyi brings is that of a person who, while grabbing a stick, can only feel "its impact against his fingers and palm" (Polanyi, 1962). Secondly, what we propose to call contextual use refers to the experience in which the tool is no longer separate from us but has now been put to use, thus becoming part of ourselves. This means, to resort to the same example, that the stick is now used as a probe to reach objects that could not be reached otherwise. In Polanyi's own words, "our awareness of its impact on our hand is transformed into a sense of its point touching the objects we are exploring" (Polanyi, 1962). This implies that the relationship established with the tool is such that the tool itself has become part of our cognition. Polanyi described this process as "dwelling in the tool", and it is at the basis of any process in which our ability to act in the world is distributed across tools, thus extending our cognition (Clark, 2003).

Since a tool is defined by its functionalities, which can be determined prior to its use, it follows that proficiency of use can be objectively assessed by looking at the degree of control that the user exhibits over the functionalities of the tool that is being used.

As mentioned above, when moving from the operational use of a tool to its contextual use, the term use comes to refer to a different type of relationship with the tool - the one in which it becomes a sort of extension of 
oneself and therefore of one's cognition, adding new capabilities to one's own cognitive repertoire (Bardone, 2011).

The first consequence that we can draw from this is that the tool is re-described depending on the context of its application. Such re-description, albeit not free from constraints, is driven by perceived affordances, which hold the key to understanding the distinction between operational and contextual use of technology tools. So, a chair affords sitting and stairs afford climbing (Gibson, 1979). It is worth stressing that an affordance should not be mistaken for the functionality of the tool at hand. That is because the very nature of an affordance is ecological, which means that an affordance points both ways, to the environment, and to the agent (Gibson, 1979).

It follows that, to a certain extent, the tools at hand are not merely used but appropriated and re-appropriated (e.g., Bardone and Shmorgun, 2013; Derboven, Geerts and De Grooff, 2016; Salovaara, 2012). This means that the teacher will situate the tool at hand in his/her own context. Besides, the use of the tool cannot be determined prior to its use (Aagaard, 2017; Hamilton and Friesen, 2013). This means that contextual use is characterized by a certain degree of openness. The use of the tool is, in other words, polysemic or open.

The same tool can serve different purposes, and this depends chiefly on the context in which the tool is situated. As Melvin Kranzberg (1986) once put it, "Technology is neither good nor bad: nor is it neutral."

\section{Aims}

In terms of operational use, SM is defined by its functionalities as built by the designer (e.g., functionalities for typing and editing texts, creating graphic images, videos, etc.) to facilitate its use in a virtual environment. However, when it comes to using it in a context, then affordances are perceived only by the user and the specific purpose of use. So, in the case of pedagogical affordance, a teacher adapts, for example, a YouTube video on the Solar System to teach a physics lesson about how the Earth and other planets revolve around the Sun. Here, the teacher ensures that the video is relevant to the lesson and it is not too long in order to stimulate interest among students. Also, it has some practical implications. Therefore, it is important that we involve teachers because at the contextual level (in a pedagogical context), the affordances are rooted in teachers' perception. Hence, the aim of the study is not to have a large sample of teachers but to show the evidence of the existence of two different types of educational use of SM and this could be done using only few teachers. So, in our interview with teachers, we wanted to find out how their relationships evolve around SM pedagogically.

\subsection{Research Questions}

The following research questions were outlined to meet the aims of the study:

1. How do teachers articulate their use of SM in education operationally and contextually?

2. What makes SM a pedagogical tool for teaching and learning?

3. What does not constitute pedagogical use of SM in the classroom?

4. What kind of support do institutions provide towards SM use in education?

\section{The Methodology of the Research}

\subsection{Sampling and Participants}

Purposive sampling was used to identify and select teachers who have the skills and knowledge about SM and have used it in their teaching activities (Aguinis and Lawal, 2012; Creswell, 2013; Teddlie and Yu, 2007). The selection process involved teachers who taught high(secondary) school grades 7-10 (children aged 13-16) across Estonia and who had at least one year of teaching experience with SM. Emails with cover letters and consent forms were sent to participants requesting their consent and explaining their rights as participants in the study. After obtaining written consent from participants, a pseudonym was assigned to each of them to maintain their anonymity (Creswell, 2013). One limitation in sampling was teachers' readiness to have the interview in English (most teachers teach in Estonian, but the researcher conducting the interviews did not speak Estonian).

In any qualitative study, there is a possibility that a researcher's background, interest, role as well as his/her experience will affect the whole study, in particular the data collection and analysis (Creswell, 1998; Sword, 1999). While such influence is inevitable, it is important to situate the study explicating the roles played by the different authors of the paper so as to increase their reflexivity (Horsburgh, 2003). The first author conducted the data collection and led both the design of the study and the data analysis. The first author is an experienced 
high school teacher with over 20 years of experience. The other authors were involved in the design of the study and data analysis. Thus, the mention of a researcher's reflexivity in terms of interest, role, biases, and philosophy might give the reader some ideas about their expertise and how these could indirectly impact the study

\subsection{Data collection and analysis}

A semi-structured interview protocol by LeCompte and Schensul (1999) for the qualitative study was modified and reviewed by experts before it was used for the interview (see Appendix I). Semi-structured interviews allow teachers to be heard (Flick, 2006) and are also suitable for studying teacher cognition (Adamson, 2004). The interviews were carried out in a period of four months (May-September) in 2019 and were aimed at getting a close-up on teachers' experience and perspectives about teaching with SM in their respective schools. The purposive criterion sampling helped to obtain and record evidence-based practices of teaching with SM. Hence, participants were selected according to the following criteria: nature of the participant's work, experience of teaching with SM (at least one year of teaching with SM was required), and the consequences of teaching with SM. Finally, eleven teachers were selected. All eleven participating teachers were selected from the public and private high schools in Estonia. The sample consisted of eleven teachers teaching biology, mathematics, physics, English, English literature, and arts in grades 7-9. Ten (90\%) participants were female teachers while one (10\%) was male. In terms of teaching experience, seven participants (64\%) had 10-35 years of experience and four (36\%) had 2-9 years of experience (see Appendix II). Participants were given the option to select their interview setup preferences from a list of interview categories. While two participants opted for face-to-face interviews, the rest settled for an online video interview mediated by Zoom (https://www.zoom.us/). All interviews were video-recorded and notes were taken in some instances. Participants were asked open-ended questions to elicit an explicit perspective on their experiences in teaching with SM (see Appendix I).

We used latent content analysis. It is a systematic process of coding large amounts of textual information. The latent content analysis seeks to establish trends and patterns in the words used, their frequency, their relationships, and discourses in communication (Creswell, 2013). It is also a tool for research analysis because it aids in the reporting of common data issues (Vaismoradi et al., 2013). We adopted latent content analysis because we wanted to examine the document's content and explain its characteristics.

So, we gave an overview of the data by inductive and deductive coding. Subsequently, we highlighted all meaningful sentences, words, extracts (from sentences) that contain some relevant and critical information on a participant's experience with SM. These codes were later organized into categories. Then we combined the highlighted statements and organized them into sub-categories, hence creating a collection of meaning and eventually became the topics. Based on the research objectives, four main categories (topics) emerged from teachers' teaching experience with SM (see tables 2-5).

\section{Findings}

All the participants (teachers) whom we interviewed gave a lot of positive and encouraging perspectives about using SM in teaching. In sharing their thoughts and perspectives, participants presented the professional use of SM from the classroom context. Again, they highlighted the advantages and constraints they encountered in using these tools during their line of duty. The following are the thoughts and views presented which constituted the categories that emerged from our analysis.

\subsection{SM Technology in the classroom}

Here, teachers integrating technology into the classroom were observed from two conceptual levels: the operational and the contextual level (see Table 2). Generally, teachers use SM technology in many ways (operational and contextual) to enhance their teaching and learning activities. Through SM teachers can seamlessly pass on information to students, store and access learning resources and make the learning process more collaborative and interactive.

Specifically, at the operational level, we noticed that teachers' focus was on using the operational affordances in the tool for sharing, managing, and accessing learning resources. Thus, SM provides students with the opportunity to safely keep their lesson materials in electronic folders for easy access, sharing, and retrieval. This is possible through links to learning resources and multiple learning platforms, which students frequently use since it gives them a diverse range of experiences. Essentially, SM technology allows students to access their 
saved lesson files anytime and anywhere, thus enabling those students absent from school to follow the lessons remotely (see Table 2 ).

However, at the operational level, all these activities are not pedagogical, but they are part of the affordances as designed and not context-specific.

Meanwhile, at the contextual level, we have noticed that teachers have gone beyond the operational affordances. Here, they make meaningful use of the SM technology in the context of their teaching and learning, thus making learning more interactive and informative (see Table 2).

Consequently, using SM technology in this context is perceived as pedagogical because the teacher was able to apply his/her pedagogical and content knowledge to bear on the selection of the video. This means that he/she did not just share any video on the lesson but critically assessed its relevance in terms of content, volume and impact it would have on the learning process. Besides, the teacher was able to ask the students some questions as a task to elicit their feedback as well as help with his/her own reflection.

Table 2: SM technology in the classroom

\begin{tabular}{|c|c|c|}
\hline Sub-Category & Result & Extracts \\
\hline \multirow[t]{5}{*}{ Operational level } & $\begin{array}{l}\text { Storage, sharing } \\
\text { and retrieval of } \\
\text { materials }\end{array}$ & $\begin{array}{l}\text { any activity with Facebook can be easily saved, downloaded or shared, } \\
\text { and it is visible to the members of the group ... and it is all in the same } \\
\text { place. (Jane) }\end{array}$ \\
\hline & Information & $\begin{array}{l}\text { students can search for information with YouTube so quickly to do their } \\
\text { assignments. (Triin) }\end{array}$ \\
\hline & & $\begin{array}{l}\text { I also use Google Classroom to give links and other resources to my } \\
\text { students to use in their work. (Evelin) }\end{array}$ \\
\hline & & one good thing about SM is that the student always has access to lessons \\
\hline & Access & $\begin{array}{l}\text { materials later or if students forget something at home, they can use the } \\
\text { links and download it from the Google Classroom. (Gerli) }\end{array}$ \\
\hline \multirow[t]{5}{*}{ Contextual level } & $\begin{array}{l}\text { Interactive } \\
\text { learning }\end{array}$ & $\begin{array}{l}\text { My students watch a YouTube video to see how the bonds in the double } \\
\text { helical structure of DNA are formed ...very interactive, interesting, and } \\
\text { revealing. (Kaja) }\end{array}$ \\
\hline & & $\begin{array}{l}\text { I select, for example, a short YouTube video on the Solar System during a } \\
\text { physics lesson which the students observe how the planets revolve around } \\
\text { the Sun...and then they answer some questions in their workbooks. } \\
\text { (Kristjan) }\end{array}$ \\
\hline & & $\begin{array}{l}\text { the students watch YouTube video during a lesson to hear how some } \\
\text { scientific words in biology are correctly pronounced. (Triin) }\end{array}$ \\
\hline & & $\begin{array}{l}\text { I like to use more of SM apps, e.g., Twitter as a class account so that we } \\
\text { can learn as a class of how we can convey information, who we make it } \\
\text { visible to and how we make sure it's credible. (Zara) }\end{array}$ \\
\hline & Information & $\begin{array}{l}\text { My students take pictures of frogs with Instagram to show all the } \\
\text { observable characteristic features on frogs during a biology lesson. (Zara) }\end{array}$ \\
\hline
\end{tabular}

\subsection{Positive perceived pedagogical affordances}

Positive perceived pedagogical affordances of teaching using SM are divided into sub-categories such as management of resources, flexibility to learn, participation in learning, and availability of resources (see Table 3).

These are affordances that are purposefully and directly linked to ensuring a positive perceived pedagogical outcome. The highlights include making learning less stressful and interesting through easy access to information and interactive learning resources. Also, the fact that students could remotely collaborate and communicate through interactive informal learning protocols outside the classroom format makes learning with SM innovative and diverse because it comes with multiple learning options and opportunities. 
Wilson O. Otchie et al 
Table 3: Positively perceived pedagogical affordances

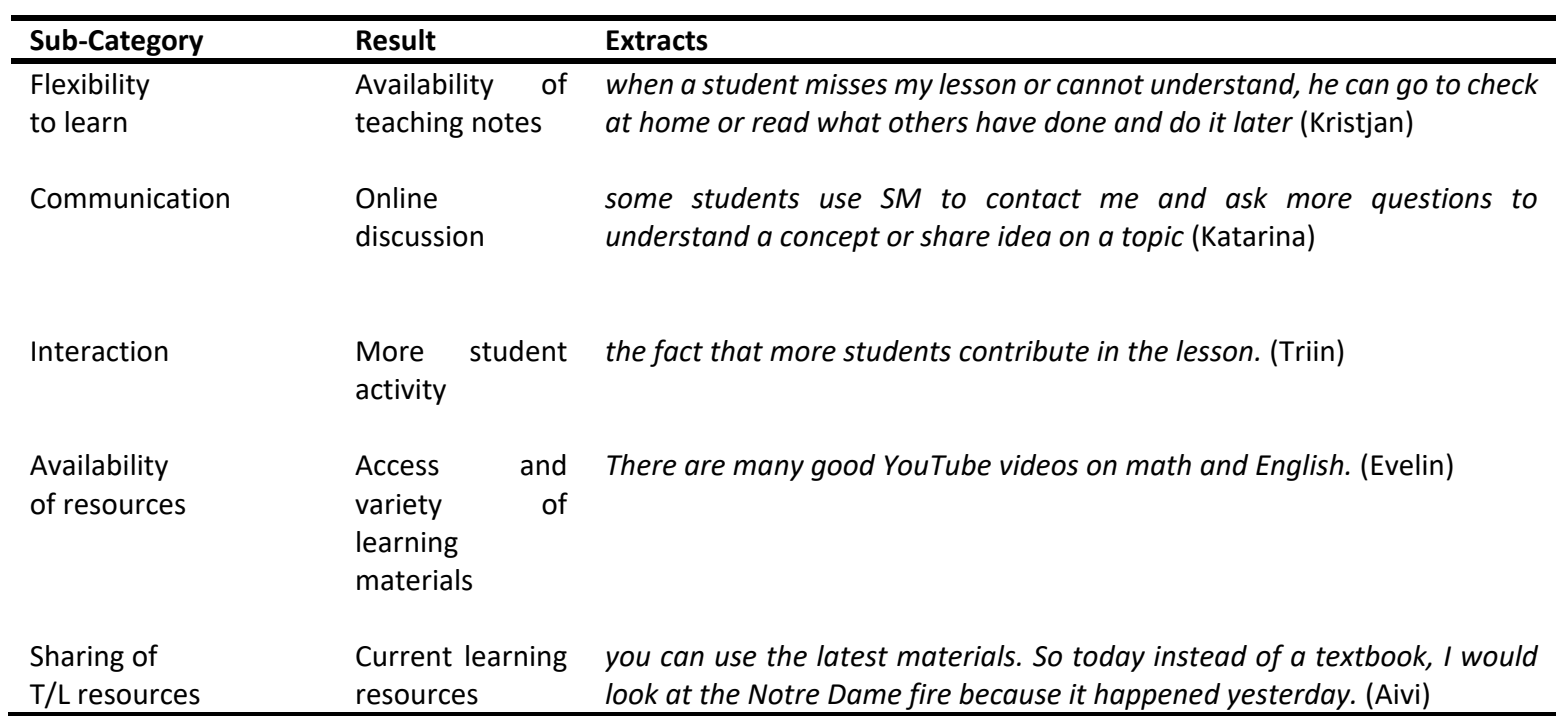

\subsection{Negatively perceived pedagogical affordances}

This is the category for using SM for anything other than for learning or teaching (see Table 4). These are affordances that may be beneficial to the user but are ineffective in the sense of pedagogical context. They are regarded as negative pedagogical affordances because they produce no positive pedagogical outcomes. Some texts or websites that students access in a class, for example, are distracting and divert their attention away from the lesson. While these benefits may temporarily satisfy a student's curiosity, they are viewed negatively in the pedagogical sense, that is, not relevant to lesson being taught in class.

Teachers are not immune to the negative effects of these pedagogical affordances. They're also worried because they're still having trouble with knowledge and time management: for example, teachers must be able to pick appropriate videos and other multimedia resources for a lesson within a certain amount of time. To put it another way, they are entangled in a web of choice and time.

Table 4: Negatively perceived pedagogical affordances

\begin{tabular}{|c|c|c|}
\hline Sub-Category & Result & Extracts \\
\hline \multirow[t]{2}{*}{$\begin{array}{l}\text { Students' } \\
\text { concentration }\end{array}$} & $\begin{array}{l}\text { Distraction } \\
\text { adverts } \\
\text { messages }\end{array}$ & $\begin{array}{l}\text { So, if you set them a task, they wander off to some other page or get this } \\
\text { practice by a message coming from somebody else. (Katarina) }\end{array}$ \\
\hline & & $\begin{array}{l}\text { Sometimes students get carried away when using SM... they sometimes } \\
\text { look at the pages they're not supposed to. (Gerli) }\end{array}$ \\
\hline \multirow[t]{2}{*}{ Time management } & Time overlap & $\begin{array}{l}\text { Using FB class group, it looks like my work time and free time is mixed. } \\
\text { (Mirjam) }\end{array}$ \\
\hline & Information choice & $\begin{array}{l}\text { Sometimes I get carried away when preparing the lesson because I have } \\
\text { difficulty in managing a lot of information. (Evelin) }\end{array}$ \\
\hline $\begin{array}{l}\text { Students' } \\
\text { conduct }\end{array}$ & Cyber-bullying & $\begin{array}{l}\text { One negative thing is internet bullying... what is going on I cannot see if I } \\
\text { sit in the classroom. (Kristjan) }\end{array}$ \\
\hline
\end{tabular}

\subsection{Support for social media}

This study looks at how educational institutions contribute to using SM technology and other interactive digital environments in teaching and learning. Institutional support for SM use in schools comes with infrastructural development and staff training (see Table 5).

In terms of infrastructural development, all our participants had all the required technological infrastructure in their schools. According to them, they had very good and fast internet with strong Wi-Fi, availability of tablets for both teachers and students, modern computer labs, and other digital tools such as whiteboards and overhead projectors. Some of them had educational technologists in their schools who helped with issues in the context of digital teaching resources. They also had periodic training workshops in ICT and most importantly, all 
teachers were given the freedom to use any digital tool they found good and relevant to their lessons. In addition, we know that $97 \%$ of students in that age group had already in 2016 the possibility to use their smart phones for learning (see Pedaste et al., 2017). This gives teachers the leverage in terms of competence and confidence in using technology to teach.

Table 5: Support for social media

\begin{tabular}{|c|c|c|}
\hline \multicolumn{2}{|l|}{ Sub-Category } & Extracts \\
\hline $\begin{array}{l}\text { Infrastructural } \\
\text { development }\end{array}$ & $\begin{array}{l}\text { Provided } \\
\text { resources }\end{array}$ & $\begin{array}{l}\text { Every teacher has access to a separate computer, and we have tablets } \\
\text { and laptops for students. (Kristjan) } \\
\text { Management is very fond of people (teachers) bringing in technology to } \\
\text { classes so they're encouraging any use of it (social media). (Kaja) } \\
\text { All students have computers... and assigned laptops in class. The school } \\
\text { also supports BYOD*. (Mirjam) }\end{array}$ \\
\hline Staff development & $\begin{array}{l}\text { Provided } \\
\text { training }\end{array}$ & $\begin{array}{l}\text { A regular training on how to teach with technology is provided and we } \\
\text { find it very useful. (Kristjan) }\end{array}$ \\
\hline & ICT workshops & $\begin{array}{l}\text { The school supports teachers to participate in ICT workshops in Estonia. } \\
\text { (Evelin) }\end{array}$ \\
\hline
\end{tabular}

*BYOD: Bring your own device

\section{Discussion}

This study was meant to illustrate concretely the distinction between the use of SM in teaching in terms of operational and contextual use with some practical examples. So, we explored how teachers articulate their teaching experiences with SM in terms of its perceived pedagogical use within the context of teaching in high schools. Then, we carried out in-depth interviews with participating teachers in order for them to describe how they operate SM ecology, how they use it pedagogically, as well as their perspectives and challenges, if any. Subsequently, we have four categories to help address the research questions in the study.

First, in trying to address the ambiguity surrounding the use of SM in education, we theorize about teachers' relationship with technology by resorting to the distinction between operational use and contextual use, which is chiefly rooted in Polanyi's and Gibson's contribution.

For instance, at the operational level, SM has been predefined and therefore a teacher could determine what to do with it based on its functionalities and limitations. This was revealed in the findings where some teachers see SM as a tool that helps them to download and share learning resources to their students. This is what Norman (1988) calls perceived affordances. However, at the contextual level, the use is open and subject to the user's relationship with the technology(tool) and the contexts. Hence, the user is responsible for deciding the contexts in which to use the technology, and this goes beyond its operational limitations. So, in order for a teacher to contextualize SM pedagogically, he/she needs to dwell in the technology as Polanyi describes it, to be able to perceive these pedagogical affordances.

Affordances are grounded in perceptions (Gibson, 1986), and as Barsalou (2015) explains, perceptions could be likened to a force that detects and picks useful hints from the environment to help one's actions. In our quest to integrate technology into teaching, it is important to acknowledge the role of our perceptions in this context. Perceptions are dynamic processes that afford, for instance, teachers to try new things, experience emerging technologies, test new concepts, and develop new strategies and ways to solve emerging problems (Hamilton, Rosenberg, and Akcaogluet, 2016; McKenney and Roblin, 2018). Hence the decisions we make are reflections of our experiences in the environment (Kopcha et al., 2020). This supports Gibson's affordance concept, which is of the view that, the way we think and react is a reflection of our experiences with people and objects in our surroundings.

In essence, perceptions could be influenced by a teacher's experience with technology (Kopcha et al., 2020). Meanwhile, experiences could have direct links to a relationship with technology and regular interactions with the technology. This means relationships produce experience. For instance, a negative experience with technology constrains one's perceptions about possibilities in the technology, while a positive experience with technology boosts one's perception about the potential and possibilities offered by the technology. This means a teacher's positive encounter with technology could result in a positive experience and positive perceptions 
which could potentially lead to meaningful use of technology in the context of teaching. A teacher must establish a relationship with technology in order to gain experience. In so doing, the technology becomes part of their cognition and potentially enables them to perceive most of the pedagogical affordances to be able to contextualize its use. This will potentially help to maximize SM use in teaching and perhaps minimize the perceived risks.

So, at the operational level, SM use was basically as it was designed by the software developers and therefore the operational affordances (functionalities) already exist with the application (Angeli and Valanides, 2018). Here, teachers try to gain control of its functions and to establish a basic relationship with its operations. As has been revealed in the findings, at the operational level teachers use SM to basically communicate, share information, post or review contents, make friends, or watch trending news, among others. More so, it affords teachers to add or delete text, share photos, videos, blogs, etc. As we have seen, the teachers' focus is more on how to acquire the operational skills and competencies to enable them to use the tool as designed, which is undoubtedly very important and necessary (Bernhard, Recker, and Burton-Jones, 2013; Norman, 1988).

That is why a few teachers' responses indicate that SM is basically a tool for connecting students and sharing learning resources in a more conveniently seamless manner. Nonetheless, most of the teachers regard SM as a tool that has the affordances to teach from a student-centred perspective, where they deliver lessons using interactive YouTube videos through a collaborative and active learning approach. This supports studies that view SM as an interactive and student-centred platform (Manca and Ranieri, 2013; Siemens and Weller, 2011; Vygotsky, 1978).

However, unlike operational use, there is no clarity on how a teacher transitions into acquiring contextual skills and competencies in a tool. Following Polanyi (1962), we may argue that the process of acquiring such skills and competence is rooted in the development of tacit knowledge, which is personal and experiential. So, contextual affordance is characterised by a degree of openness and it allows the users to determine the context; thus making the contextual use more uncertain, unstructured, and tacit, because it can go either way, either for good or ill (Gibson, 1978)

Angeli and Valanides (2018) observe in their study that affordances concern the process of thinking creatively about how one can transform the operational affordances of a tool into pedagogical (contextual) affordances to bring about goals. Operational affordances alone cannot do that. So, the need to innovatively integrate operational skills with experience to achieve a pedagogical impact. Our introduction of the terms "operational and contextual affordances" is a step to understanding the nuances in effectively using technology.

For example, teaching a lesson on the solar system using YouTube video. The teacher's creativity and experience, as well as the video content, its suitability for that class, the skills and confidence in the presentation, and the level of interactivity of the video and the spatial visualization, are all factors in making it pedagogical. This shows that knowledge in technology, content, and pedagogy (Mishra and Koehler, 2006) is not sufficient to make teachers use technology effectively. They need more experience and skills which are rooted in tacit knowledge. This was also disclosed in our interviews where teachers described how their experiential and operational skills in SM contributed to the effective preparation and presentation of lessons with the SM tools. As a result of their regular dialogue with the tools, the participating teachers' pedagogical use of SM eventually demonstrated a degree of control and confidence with tools. This supports Polanyi and Gibson's assertions about the importance of relationships with tools.

Indeed, contextualizing a tool for educational use has revealed some flaws in the TPACK paradigm (Mishra and Koehler, 2006). According to the TPACK concept, teachers cannot be effective with technology unless they have knowledge of technology, content, and pedagogy. Rather, the concept seeks to improve their operational skills in employing technology in the way that it was intended. As a result, it is critical that we focus on teachers' experienced capabilities, which Polanyi refers to as tacit knowledge, in order for them to contextualize technology in their teaching activities. We realize meaning and purpose in using technology (SM) appropriately at the contextual level.

The categorical areas of negative and positive perceived pedagogical affordances of teaching with SM directly hinge on the level of relationship with the tool, as we have just pointed out. According to one participant, her 
students sometimes get distracted when using SM for learning in class They sometimes turn to different sites to watch movies, play games, or chat with friends.

Here, the technology becomes a distraction to the teaching and learning process because it takes the student's attention from the lesson. The reason teachers and stakeholders have divided opinions about technology integration in the school curriculum (Otchie and Pedaste, 2020).

On the other hand, technology is used in ways beneficial to the learner because of the context of use. In terms of the benefits of SM technology in education, another participant perceived technology as a tool that facilitates students learning because all learning materials are readily available and accessible even for those absent from school.

These two contexts demonstrate two diverse uses of the same tool within the context of teaching and learning. On one hand, even though the use was beneficial to the learner, it was perceived as a distraction because of the context. Indeed, the student could have used it in the context that is purposeful and pedagogically relevant. Also, it is important to mention that this perceived abuse which we termed "negative affordances" of the tool by the student was a result of his/her relationship with technology. Alternatively, using technology to access online learning resources is beneficial to the user within the context. Hence, we describe it as positive affordances. This clearly demonstrates that in contextualizing technology, the onus rests on the user because he/she determines the context of use.

The institutional support for teachers using SM in their teaching activities was one of the categories that emerged from our research. In contrast to previous studies, that schools lacked technological infrastructure and support (Dillenbourg, 2008; Taghizadeh, and Hasani Yourdshahi, 2020), all participants expressed satisfaction with the technological infrastructure and support provided by their schools.

Besides technological support, funds, and other necessities, management must also motivate teachers to give their best. Our findings revealed that access to ICT resources, such as computers, laptops, tablets, and other relevant digital devices, was not a problem for participating teachers and their students. However, there were a small number of students who did not have regular internet access or personal computers at home, confirming the findings of Rasheed and colleagues (2020), who found that there is inequality in technical support and access among students.

According to participants of the current study, the teachers undergo periodic training in computer technology in their schools and attend workshops organized in Estonia. However, we noticed from the interviews that most training courses were centred more on the operational level than the pedagogical level, thus making the teachers inclined towards using technology more operationally than pedagogically.

\section{Conclusion and limitations}

Essentially, the findings of the study underpin the assertion that SM is a potential pedagogical resource for teaching and learning. This was demonstrated by the participants' ability, interest, and willingness to teach with SM because it made their lessons more interactive, interesting, and innovative. Also, many teachers are teaching with SM tools because it affords them the opportunity to connect remotely to their students anytime and anywhere, especially those who were absent from school, allowing the students to follow the lessons from any location. Furthermore, it is important to mention that these technologies also allow teachers to remotely access the learning resources of their colleagues from different schools. Likewise, students' interest in learning has increased, as they find learning more flexible and get quick feedback and easy access to teaching and learning resources.

Regardless of the benefits of teaching and learning with SM, both teachers and students also encounter some significant challenges, which could potentially become a setback to the integration of these technologies into the classroom. Bringing this to the attention of teachers and other stakeholders can potentially help them have updates on these issues in order to be aware of and identify the potential constraints and limitations ahead of its possible integration. 
For instance, teachers' negative perceived pedagogical uses such as spending too much time on lesson preparation and the overlap of working time and social time could be researched further. Also, the distractions some students encounter with SM during lessons could be addressed when both teachers and students acquire more knowledge about SM and, most importantly, appreciate the perceived pedagogical affordances it provides. This also confirms the importance of using technology in education generally and specifically in pedagogy. Thus, going forward, it is necessary that teachers establish stronger relationships with technology tools in order to understand the technology tools they use for pedagogy. Finally, and most importantly, the study proposes that teachers and students must be given unrestricted access to these technologies so that they can have regular dialogue with these technology tools in order for them to develop skills and confidence, gain control of using them, and discover more affordances for pedagogy.

However, the study also encountered some limitations which need to be considered going forward. The first and major limitation was the time it took to have the small number of teachers involved in the study. The fundamental issue was potentially their low level of the English language skills - the mother tongue of the respondents was usually Estonian, but the data was collected in English, as the data collectors did not speak Estonian. There was a general reluctance among teachers to participate in the interview which we could attribute to their challenge with English; they might have preferred Estonian, which is widely spoken in Estonia and serve as language of instruction in the schools. Thus, unfortunately, several teachers who might have been interested could not speak English and were unable to participate. Furthermore, most teachers were unable to participate in the interviews because May and June are among the busiest months for teachers, particularly those in high (secondary) schools who are preparing their pupils for a major summative evaluation. Despite these limits, we were able to accomplish our goals during the interviews.

Indeed, the goal of this study was to define the term "usage of SM." So, the terms "operational and contextual affordances" were coined as a result. Despite their differences, these two concepts work together to make effective classroom technology use possible. When it comes to leveraging technology, we also established the importance of relationships. As a result, a greater knowledge of these principles could make technology training for pre-service teachers easier.

\section{References}

Aagaard, J., 2017. Breaking down barriers: the ambivalent nature of technologies in the classroom. New Media and Society 19(7), pp.1127-1143.

Adamson, J., 2004. Unpacking teacher beliefs through semi-structured interviewing: insights into the interviewing process in context. Journal of Language and Learning, 2(2), pp.114-28.

Aguinis, H., and Lawal, S. O., 2012. Conducting field experiments using e-Lancing's natural environment. Journal of Business Venturing, 27(4), pp.493-505.

Alias, N., Siraj, S., Daud, M. K. A. M., and Hussin, 2013. Effectiveness of Facebook based learning to enhance creativity among Islamic studies students by employing isman instructional design model. Turkish Online Journal of Educational Technology, 12(1), pp. 60-67.

Alt, D., 2017. College students' perceived learning environment and their social media engagement in activities unrelated to class work. Instructional Science, 45(5), pp.623-643. http://dx.doi.org/ 10.1007/s11251-017-9418-0

Al Alwan, A., Rana, N. P., Dwivedi, Y. K., and Algharabat, R., 2017. Social media in marketing: A review and analysis of the existing literature. Telematics and Informatics, 34(7), pp.1177-1190.

Andersson, A., Hatakka, M., Grönlund, A. and Wiklund, M., 2014. Reclaiming the students - coping with social media in 1:1 schools. Learning, Media and Technology, 39 (1), pp.37- 52.

Angeli, C., and Valanides, N., 2009. Epistemological and methodological issues for the conceptualization, development, and assessment of ICT-TPCK: advances in technological pedagogical content knowledge (TPCK). Computers and Education, 52(1), pp.154-168.

Angeli, C., and Valanides, N., 2018. Knowledge base for information and communication technology in education. J. Voogt, G. Knezek, R. Christensen and K-W Lai (eds.), Second Handbook of Information Technology in Primary and Secondary Education. Cham; Springer. https://dx.doi.org/10.1007/978-3-319-71054-9 26

Bardone, E., 2011. Seeking chances: rom biased rationality to distributed cognition. Berlin, Heidelberg: Springer.

Bardone, E., and Shmorgun, I., 2013. Ecologies of creativity: smartphones as a case in point. Mind and Society, 12(1), pp.125-135.

Barron, B., 2004. Learning ecologies for technological fluency: Gender and experience differences. Journal of Educational Computing Research, 31(1), pp.1-36

Barrot, J. S., 2018. Facebook as a learning environment for language teaching and learning: a critical analysis of the literature from 2010 to 2017. Journal of Computer Assisted Learning, 34(6), pp.863-875 
Barsalou, L. W., 2015. Situated conceptualization: Theory and applications. In: Y. Coello \& M. H. Fischer (Eds.), Perceptual and emotional embodiment: Foundations of embodied cognition (pp. 19-45). New York, NY: Routledge.

Bernhard, E., Recker, J. C., and Burton-Jones, A., 2013. Understanding the actualization of

affordances: a study in the process modeling context. In: M. Chau and R. Baskervill (eds.) Proceedings of the 34th International Conference on Information Systems (ICIS 2013). Association for Information Systems (AIS), Available at: http://eprints.qut.edu.au/63052/. [Accessed 23 May 2021]

Bruguera, C., Guitert, M., and Romeu, T., 2019. Social media and professional development: A systematic review. Research in Learning Technology, 27, pp.1-18.

Calvert, S. L., 2015. Children and digital media. Available at:http://cdmc.georgetown.edu/wpcontent/uploads/2015/03/10-calvert-hocpads-7e-v4-c10 final 2015.pdf [Accessed 11 October 2018]

Ch, A. Q., Hussain, T., Mahmood, Z., and Rasool, M. S., 2016. A comparative study between the learning style of user and non-user students of social media at elementary school level. Bulletin of Education and Research, 38(2), pp.203-209

Chen, B. and Bryer, T., 2012. Investigating instructional strategies for using social media in formal and informal learning. The International Review of Research in Open and Distance Learning 13(1), pp.87-100.

Chugh, R. and Ruhi, S., 2018. Social media in higher education: a literature review of Facebook. Education and Information Technologies, 23(2), pp.605-616.

Clark, A., 2003. Natural-born cyborgs: Minds, technologies and the future of human intelligence. New York: Oxford University Press.

Creswell, J.W., 2013. Qualitative inquiry and research design: choosing among five approaches. Thousand Oaks, CA: Sage Publications Ltd.

Creswell, J.W., 1998. Qualitative inquiry and research design: choosing among five traditions Thousand Oaks, CA: Sage Publications Ltd

Cronje, J. C., 2020. Towards a new definition of blended learning. The Electronic Journal of e-Learning, 18(2), pp. 114-121, available online at www.ejel.org DOI: 10.34190/EJEL.20.18.2.001

Davis, J. L., and Chouinard, J. B., 2016. Theorizing affordances: From request to refuse. Bulletin of Science, Technology \& Society, 36(4), 241-248.

Derboven, J., Geerts, D., and De Grooff, D., 2016. The tactics of everyday practice: a semiotic approach to appropriation. Interaction Design and Architecture. 29(29), pp.99-120.

Dillenbourg, P., 2008. Integrating technologies into educational ecosystems. Distance Education, 29(2), pp.127-140.

Dwivedi, Y.K., Mäntymäki M., Ravishankar M.N., Janssen M., Clement M., Slade E.L., Rana N.P., Al Sharhan S., and Simintiras A.C. (Eds.) 2016. Social media: the good, the bad, and the ugly. 15th IFIP WG 6.11 Conference on eBusiness, e-Services, and e-Society, I3E 2016, Swansea, UK, September pp.13-15, 2016, proceedings (Vol. 9844).

Fox, A. and Bird, T., 2017. \#any use? What do we know about how teachers and doctors learn through social media use? Qwerty. Open and Interdisciplinary Journal of Technology, Culture and Education, 12(2), pp.64-87.

Fox, J. and McEwan, B., 2017. Distinguishing technologies for social interaction: the perceived social affordances of communication channels scale, Communication Monographs, 84(3), pp. 298-318.

Galvin, S., and Greenhow, C., 2020. Writing on social media: a review of research in the high school classroom. TechTrends, 64(1), pp. 57-69. https://doi.org/10.1007/s11528-019-00428-9

Gao, F., Luo, T. and Zhang, K., 2012. Tweeting for learning: a critical analysis of research on microblogging in education published in 2008-2011. British Journal of Educational Technology, 43(5), pp.783-801

Gibson, J. J., 1986. The ecological approach to visual perception. Hillsdale, NJ: Lawrence Erlbaum Associates.

Gibson, J. J., 1979. The ecological approach to visual perception. Boston: Houghton Mifflin.

Gibson, J. J., 2015. The ecological approach to visual perception. Classic Editions. New York:Psychology Press.

Greenhow, C. and Lewin, C., 2015. Recrafting formal education: Shifting the boundaries of formal and informal learning. Learning, Media \& Technology, 40(3), 128-148.

Greenhow, C. and Askari, E., 2017. Learning and teaching with social network sites: a decade of research in K-12 related education. Education and Information Technologies, 22(2), pp.623-645.

Greenhow, C., and Chapman, A., 2020. Social distancing meet social media: digital tools for connecting students, teachers, and citizens in an emergency. Information and Learning Science, 121(5-6), pp. 331-342. https://doi.org/10.1108/ILS04-2020-0134

Greenhow, C., Galvin, S., Brandon, D., and Askari, E., 2020. A decade of research on K-12 teaching and teacher learning with social media: insights on the state of the field. Teachers College Record, 122(6), pp.23303.

Greenhow, C., Robelia, B., and Hughes, J. E., 2009. Learning, teaching, and scholarship in a digital age: Web 2.0 and classroom research: what path should we take now? Educational Researcher, 38(4), pp.246-259. https://doi.org/10.3102/0013189X09336671

Haines, K., 2015. Learning to identify and actualize affordances in a new tool. Language Learning and. Technology, 19(1), pp.165-180.

Hamilton, E. R., Rosenberg, J. M., and Akcaoglu, M., 2016. The substitution augmentation modification redefinition (SAMR) model: A critical review and suggestions for its use. Tech Trends, 60(5), pp.433-441. https ://doi.org/10.1007/s1152 8-016-0091-y

Hamilton, E., and Friesen, N., 2013. Online education: a science and technology studies perspective/education en ligne: perspective des etudes en science et technologie. Canadian Journal of Learning and Technology/La Revue Canadienne de l'Apprentissage et de la Technologie 39(2), pp.1-21 
Harvey, S., and Pill, S., 2019. Exploring physical education teachers "everyday understandings" of physical literacy. Sport, Education \& Society, 24(8), pp. 841-854. http://10.0.4.56/13573322.2018.1491002

Horsburgh, D., 2003. Evaluation of qualitative research. Journal of Clinical Nursing, 12(2), pp.307-312

Jonassen, D. H., Carr, C., and Yueh, H. P., 1998. Computers as mind tools for engaging learners in critical thinking. Tech Trends, 43(2), pp.24-32. https ://doi.org/10.1007/BF028 18172.

Kaplan, A. M. and Haenlein, M., 2010. Users of the world, unite! The challenges and opportunities of social media. Business Horizons, 53(1), pp.59-68.

Kapoor, K. K., and Dwivedi, Y. K., 2015. Metamorphosis of Indian electoral campaigns: Modi's social media experiment. International Journal of Indian Culture and Business Management, 11(4), pp.496-516.

Karkar, A. J. M., Fatlawi, H. K., and Al-Jobouri, A. A., 2020. Highlighting e-learning adoptionchallenges using data analysis techniques: University of Kufa as a Case Study. The Electronic Journal of e-Learning, 18(2), pp.136-149, available online at www.ejel.org DOI: $10.34190 / E J E L .20 .18 .2 .003$

Kerckaert, S., Vanderlinde, R., and van Braak, J. (2015). The role of ICT in early childhood education: Scale development and research on ICT use and influencing factors. European Early Childhood Education Research Journal, 23(2), 183-199. doi:10.1080/1350293X.2015.1016804

Kibuku, R. N., Ochieng, D. O., and Wausi, A. N., 2020. e-Learning challenges faced by Universities in Kenya: a literature review. The Electronic Journal of e-Learning, 18(2), pp. 150-161, available online at www.ejel.org DOI: 10.34190/EJEL.20.18.2.004

Kirschner, P., Strijbos, J.-W., Kreijns, K., and Beers, P., 2004. Designing electronic collaborative learning environments. Educational Technology Research and Development, 52, pp.47-66. doi.org/10.1007/BF02504675

Kopcha, T. J., Neumann, K. L., Ottenbreit-Leftwich, A., and Pitman, E., 2020. Process over product: the next evolution of our quest for technology integration. Educational Technology Research and Development, 68(2), pp.729-749. https://doi.org/10.1007/s11423-020-09735-y

Kranzberg, M., 1986. Technology and History: Kranzberg's Laws. Technology and Culture, 27(3), pp.544-560.

Krauskopf, K., Zahn, C., and Hesse, F. W., 2015. Cognitive processes underlying TPCK: mental models, cognitive transformation, and meta-conceptual awareness. In: C. Angeli and N. Valanid (Eds.), Technological pedagogical content knowledge: exploring, developing, and assessing TPCK (pp. 41-61). NY: Springer.

Krutka, D., and Milton, M. K., 2013. The enlightenment meets Twitter: using social media in the social studies classroom. Ohio Social Studies Review, 50(2). pp.22-29

Lantz-Andersson, A., Lundin, M., and Selwyn, N., 2018. Twenty years of online teacher communities: A systematic review of formally organized and informally developed professional learning groups. Teaching and Teacher Education, 75(1), pp.302-315.

LeCompte, M., and Schensul, J., 1999. Essential Ethnographic Methods (vol. 2): Ethnographers toolkit. New York, NY: Altamira Press.Manca, S., and Ranieri, M., 2013. Is it a tool suitable for learning? A critical review of the literature on Facebook as a technology-enhanced learning environment, Journal of Computer-Assisted Learning, 29(6), pp.487504.

Manca, S. and Ranieri, M., 2016. Is Facebook still a suitable technology-enhanced learning environment? An updated critical review of the literature from 2012 to 2015. Journal of Computer-Assisted Learning, 32(6), pp.503-528.

Manca, A. and Whitworth, A., 2018. Social media and workplace practices in higher education institutions: a review. The Journal of Social Media in Society, 7(1), pp.151-183.

Manca, S., Bocconi, S. and Gleason, B., 2021. "Think globally, act locally": A global approach to the development of social media literacy. Computers and Education, 160 pp.104025. DOI:10.1016/j.compedu.2020.104025

Mar, R. A., and Oatley, K., 2008. The function of fiction is the abstraction and simulation of social experience. Perspectives on Psychological Science, 3(3), pp.173-192. http://dx.doi.org/10.1111/j.1745-6924.2008.00073. x.

Macià, M., and Garcia, I., 2016. Informal online communities and networks as a source of teacher professional development: A review. Teaching and Teacher Education, 55, pp.291-307.

Mazman, S.G., and Usluel, Y.K., 2010. Modeling educational uses of Facebook. Computers in Education, 55(2), pp.444-453.

McKinney, S., and Roblin, N. P., 2018. Connecting research and practice: Teacher inquiry and Design based research. In: J. Voogt, G. Knezek, R. Christensen and K.-W. Lai (Eds.), Second handbook of information technology in primary and secondary education (pp. 1-14). Cham: Springer. https :// doi.org/10.1007/978-3-319-53803 -7_30-2

Merkt, M., and Schwan, S., 2014. Training the use of interactive videos: effects on mastering different tasks. Instructional Science, 42(3), pp.421-441 http://dx.doi.org/10.1007/s11251-013-9287-0

Mishra, P., and Koehler, M.J., 2006. Technological pedagogical content knowledge: a framework for teacher knowledge. Teacher College Record, 108(6), pp.1017-1054.

Norman, D. A.,1988. The psychology of everyday things. New York: Basic Books,

Nui, L., 2017. Using Facebook for academic purposes: current literature and directions for future research. Journal of Educational Computing Research, 56(8) pp.1384-1406.

Obar, J.A. and Wildman, S., 2015. Social media definition and the governance challenge: anintroduction to the special issue, Telecommunications Policy, 39(9), pp. 745-750.

Oliver, M., 2016. What is technology? In: N. Rushby and D. Surry (Eds) The Wiley Handbook of Learning Technology. New Jersey: Wiley-Blackwell. pp.35-57.

Oliver, M., 2005. The problem with affordance. E-Learning and Digital Media, 2(4), pp.402-413. 
Oliver, M., 2013. Learning technology: theorizing the tools we study. British Journal of Educational Technology, 44(1), pp.31-43.

Otchie, W.O. and Pedaste, M., 2020. Using social media for learning: a systematic literature review European Journal of Educational Research, 9(2), pp.889-903

Pedaste, M., Must, O., Leijen, Ä., Mäeots, M., Siiman, L., Kori, K. and Adov, L., 2017. Profilesof students who use mobile devices for the purposes of learning science and mathematics. Estonian Journal of Education, 5, 99-129.

Peters, M., and Romero, M., 2019. Lifelong learning ecologies in online higher education: Students' engagement in the continuum between formal and informal learning.British Journal of Educational Technology, 50(4), pp. 1729-1744. https://doi.org/10.1111/bjet.12803

Polanyi, M., 1962. Tacit Knowledge: Its bearing on some problems of philosophy. Review of Modern Physics, 34(4), pp.601605

Postman, N., 1970. The reformed English curriculum. In: A. C. Eurich (Ed.), High school 1980: The shape of the future in American secondary education. New York: Pitman. Available at http://www.media-ecology.org/media ecology [Accessed 15 November 2010]

Rasheed, R. A., Kamsin, A., and Abdullah, N. A. (2020, January). Students and teachers' challenges of using technology in blended learning environments. In Proceedings of the 2020 the 3rd International Conference on Computers in Management and Business (pp. 195-200).

Raut, V. and Patil, P., 2016. Use of social media in education: positive and negative impact on the students. International Journal on Recent and Innovation Trends in Computing and Communication, 4(1), pp.281-285

Ramstad, J. E. and Swenson, R., 2017. The utilization of social media in the classroom. College of Food, Agricultural and Natural Resource Sciences. Minnesota USA: University of Minnesota.

Rodríguez-Hoyos, C., Haya Salmón, I. and Fernández-Díaz, E., 2015. Research on SNS and education: the state of the art and its challenges. Australasian Journal of Educational Technology, 31(1), pp.100-111.

Salovaara, A., 2012. Repurposive appropriation and creative technology use in human-computer interaction. PhD thesis, Helsinki Institute for Information Technology HIIT Aalto University and University of Helsinki, Finland, Helsinki

Scolari, C. A., 2012. Media ecology: exploring the metaphor to expand the theory. Communication Theory, 22(2), pp.204225. http://dx.doi.org/ 10.1111/j.1468-2885.2012.01404.x

Silius, K., Kailanto M. and Tervakari, A-M., 2011. Evaluating the quality of social media in an educational context. iJET, 6(3), pp.21-27.

Siemens, G., and Weller, M., 2011. Higher education and the promises and perils of social network. Revista de Universidad y Sociedad del Conocimiento (RUSC) 8(1): pp.164-170. Available at: http://oro. open.ac.uk/28418/1/1076-1505-2PB.pdf [Accessed 12 September 2015]

Sowislo, J. F. and Orth, U., 2013. Does low self-esteem predict depression and anxiety? A meta-analysis of longitudinal studies. Psychological Bulletin, 139, pp.213-240. http://dx.doi.org/ 10.1037/a0028931

Statista.com, 2019. Social media - Statistics and Facts. J. Clement. Available at: https://www.statista.com/topics/1164/social-networks/ [Accessed 15 December 2020]

Stevenson, M., Bower, M., Falloon, G., Forbes, A. and Hatzigianni, M., 2019. By design: Professional learning ecologies to develop primary school teachers' makerspaces pedagogical capabilities. British Journal of Educational Technology, 50(3), pp.1260-1274. https://doi.org/10.1111/bjet.12743

Stewart, O. G., 2015. A critical review of the literature of social media's affordances in the classroom. E-Learning and Digital Media, 12(5-6), pp.481-501. https://doi.org/10.1177/2042753016672895

Sudha, S. and Kavitha E.S.., 2016. The effect of social networking on students' academic performance: the perspective of faculty members of Periyar University, Salem. Library Philosophy and Practice (e journal). pp.1455.

Sword, W., 1999. Accounting for the presence of self-reflections on doing qualitative research. Qualitative Health Research, 9(2), pp.270-278.

Taghizadeh, M., and Hasani Yourdshahi, Z. (2020). Integrating technology into young learners' classes: language teachers' perceptions. Computer Assisted Language Learning, 33(8), 982-1006.

Tang.Y. and Hew, K. F., 2017. Using Twitter for education: beneficial or simply a waste of time? Computers and Education, 106, pp.97-118.

Teddlie, C. and Yu, F., 2007. Mixed methods sampling: a typology with examples. Journal of Mixed Methods Research, 1(1), pp.77-100.

Tondeur, J., Van Braak, J., Sang, G. Voogt, J., Fizzer and Ottenbreit-Leftwich, A., 2012. Preparing pre-service teachers to integrate technology in education: a synthesis of qualitative evidence. Computers and Education, 59 (1), pp.134-144.

Vaismoradi, M., Turunen, H., and Bondas, T., 2013. Content analysis and thematic analysis: Implications for conducting a qualitative descriptive study. Nursing and Health Sciences, 15(3), pp.398-405. https://doi.org/10.1111/nhs.12048

Van Osch, W. and Coursaris, C., 2015. A meta-analysis of theories and topics in social mediaresearch, Proceedings of the 48th Annual HI International Conference on System Sciences, Los Alamitos, pp. 1668-1675.

Veira, A. K., Leacock, C. J., and Warrican, S. J., 2014. Learning outside the walls of the classroom: Engaging the digital natives. Australasian Journal of Educational Technology, 30(2).

Voivonta, T. and Avraamidou, L., 2018. Facebook: a potentially valuable educational tool? Educational Media International, 55(1), pp.34-48. 
Zhao, X., Lampe, C. and Ellison, N.B., 2016. The social media ecology: user perceptions, strategies and challenges. CHI '16: Proceedings of the 2016 CHI Conference on Human Factors in Computing Systems, pp. 89-100. http://dx.doi.org/ $10.1145 / 2858036.2858333$

Zoom.us. https://www.zoom.us/

\section{Appendix I}

Interview Protocol

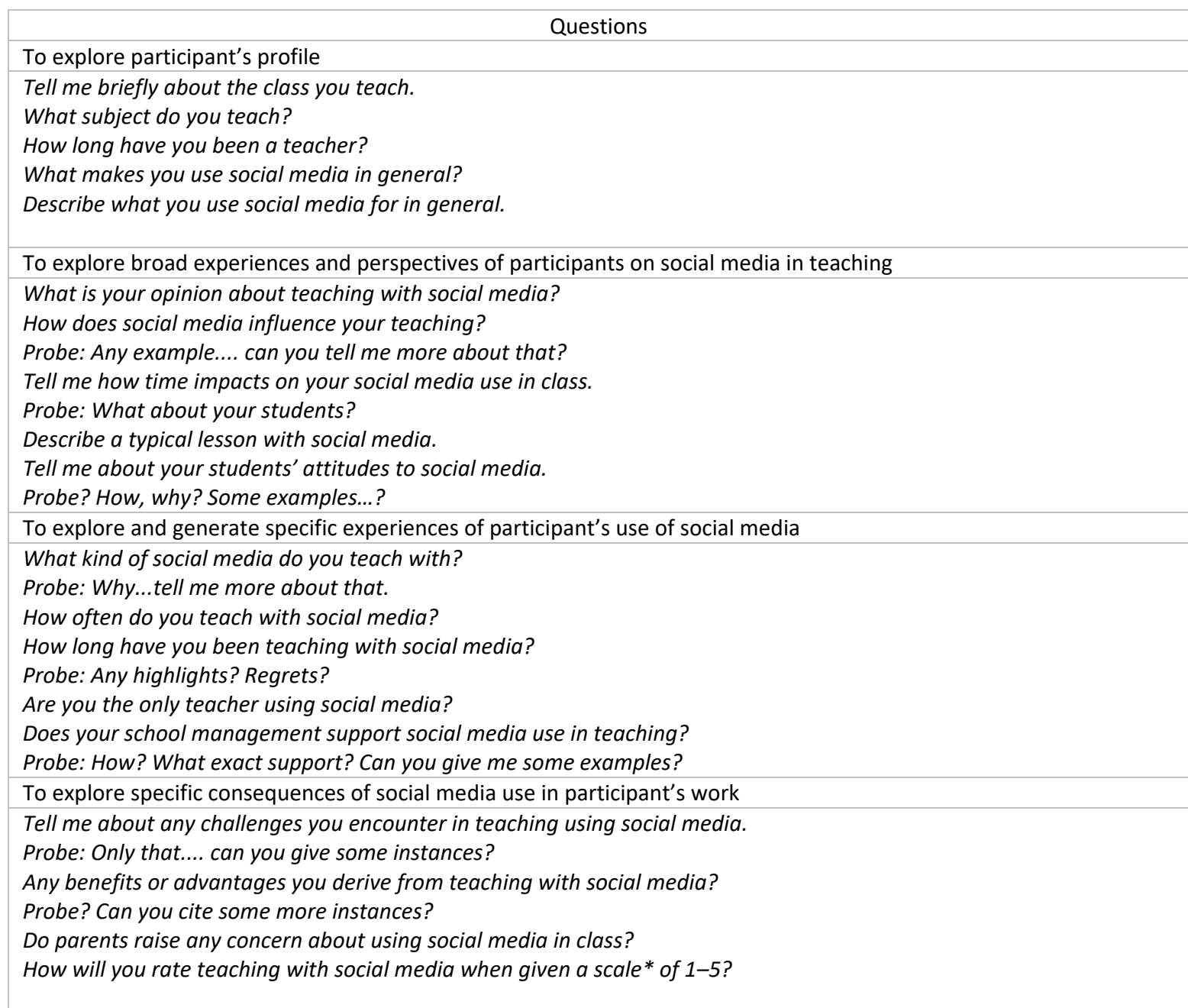

*1= poor, 2 = satisfactory, 3 = good, 4 = very good, 5 = excellent

The interview addressed the following topics:

- Background of the participants (subjects, class, and years of teaching with social media)

- How participants use social media in general

- Type of social media mostly used by participants to teach

- Frequency of teaching with social media

- How participants use social media in a typical class lesson

- Impact of social media on teaching

- The attitude of participant toward social media in education

- The attitude of parents to social media in teaching

- Schools support toward technology integration 
Wilson O. Otchie et al

\section{Appendix II}

Profile of participants

\begin{tabular}{|c|c|c|c|c|c|c|}
\hline $\begin{array}{l}\text { Pseudo- } \\
\text { nym } \\
(N=11)\end{array}$ & $\begin{array}{l}\text { Years of } \\
\text { Teaching }\end{array}$ & $\begin{array}{l}\text { Years of } \\
\text { Teaching } \\
\text { with SM }\end{array}$ & Type of SM & & Subject & Grade \\
\hline Jane & 8 & 7 & YouTube, Facebook & & Biology & 7 \\
\hline Kaja & 10 & 8 & YouTube, Facebook & & Biology & $8,9,10$ \\
\hline Kristjan & 35 & 8 & YouTube & & Physics, Maths & 8,9 \\
\hline Evilin & 20 & 7 & YouTube & & Arts, English & 7,8 \\
\hline Aivi & 25 & 10 & YouTube, Google Classroom & & English & 9,10 \\
\hline Mirjam & 16 & 5 & YouTube & & Maths & 9 \\
\hline Kristina & 2 & 2 & YouTube, Facebook & & Biology & $7,8,9$ \\
\hline Zara & 4 & 4 & $\begin{array}{l}\text { YouTube, Facebook, } \\
\text { Classroom, Instagram }\end{array}$ & Google & $\begin{array}{l}\text { English, } \\
\text { Literature }\end{array}$ & $7,8,9$ \\
\hline Triin & 6 & 6 & YouTube, Google Classroom & & Biology & $8,9,10$ \\
\hline Katarina & 11 & 7 & YouTube, Instagram & & Arts & $7,8,9$ \\
\hline Gerli & 15 & 8 & YouTube, Google Classroom & & Maths & 9,10 \\
\hline
\end{tabular}

